\title{
The Strategies of the Players of an RPG Game in the Context of Water Resources Management: an analysis based on the Discourse of the Collective Subject
}

\author{
As Estratégias dos Jogadores de um Jogo de RPG no Contexto da Gestão dos \\ Recursos Hídricos: uma análise a partir do Discurso do Sujeito Coletivo
}

\author{
Fernanda P. Mota' ${ }^{1}$, Míriam B. Born' ${ }^{\mathbb{D}}$, Marilton S. Aguiar' ${ }^{\mathbb{D}}$, Diana F. Adamatti' ${ }^{1}$
}

' Federal University of Rio Grande, Rio Grande, Rio Grande, RS, Brazil

\begin{abstract}
Games are widely used in Education because they enable analyzing strategies that come close to reality. In Environmental Education, the game helps understand a particular theme and allows the observation of the approach from a player's perspective. In this way, each person can develop strategies that $s /$ he considers relevant in the game. This study analyzes players' strategies in an RPG (Role-Playing Game) in water resources. This work's main contribution is an empirical and qualitative study on individuals' motivation and how they developed their strategies. As a result, we present the analysis of the players' habits through a semi-structured interview, which resulted in a set of speeches based on the Collective Subject Discourse (CSD).
\end{abstract}

Keywords: Collective Subject Discourse; Environmental Education; Water resources; CSD

\section{RESUMO}

Este estudo apresenta uma análise das estratégias utilizadas por jogadores de um RPG (Role-Playing Game) no contexto de recursos hídricos. Os jogos são amplamente utilizados na Educação pois possibilitam a análise de estratégias que se aproximam da realidade. No contexto da Educação Ambiental, o jogo auxilia no processo de compreensão de um determinado tema e permite a observação das estratégias a partir da perspectiva de um jogador, assim, o indivíduo pode elaborar estratégias que considera relevantes no jogo. A principal contribuição deste trabalho é um estudo empírico e qualitativo sobre a motivação dos indivíduos e como eles elaboraram suas estratégias. Como resultados, apresentamos a análise dos hábitos dos jogadores por meio de uma entrevista semiestruturada, a qual resultou em um conjunto de discursos, baseados na técnica do Discurso do Sujeito Coletivo (DSC).

Palavras-chave: Discurso do Sujeito Coletivo; Educação Ambiental; Recursos Hídricos; SC 


\section{INTRODUCTION}

Management, Education, and Environmental Technology are relevant themes and bring many discussions to society. Foleto (2018) mentions that society's quality of life is related to human, industrial and agricultural activities. In this context, natural resources must be increasingly sustainable, guaranteeing a good quality of life for future generations. According to Wahrlich et al. (2020), for the planet to become more sustainable, environmental, economic, and social issues need to be considered.

In the context of a hydrographic basin, as reported by Barbosa et al. (2019), the water resource represents the leading natural and renewable element, so that it is possible to measure the availability and distribution of water, as well as to carry out efficient and sustainable planning of the various uses of this water. Hydrological information is indispensable. Another critical factor to be considered is the inequality of social relations, considering that they are responsible for the use, allocation, and conservation of the resource (Chacon-Pereira et al., 2018). In this way, we sought possible solutions every year related to natural resources management (Adamatti et al., 2005). Thus, in the face of this problem, some studies have investigated the representation of the conflict negotiation process in the participatory management of the use of water resources, helping to understand this problem and exploring the development of good practices and strategies that help in this area (Jacobi and Francalanza, 2005).

In this scenario, it is essential to study resources that contribute to society's perception of the problem and education and environmental management. In this way, Lima (2008) cites the importance of games in education is evident. The game and how this activity influences individuals' lives have been researching and scientific investigation subjects. Vygotsky (1988) points out that one of the learning processes stems from individuals' interactions in a given situation. The ludic game and the RPGs (Role-Playing Game), also known as strategy games, contribute to these individuals' elaborating ate and exercising an imaginary plan according to previously specified rules or representing society's roles. 
This work's case study refers to the participatory negotiation of conflicts in the Lagoa Mirim and São Gonçalo Canal hydrographic basin, located in southern Brazil. It also offers an analysis of the Collective Subject Discourse (CSD), using RPG in Natural Resource Management. These analyzes originated from interviews with individuals who participated in the RPG sessions defined for this problem.

This article is structured as follows. Sections 2 presents the theoretical bases of this work, the collective subject's discourse, and the strategic and serious games. Section 3 presents the methodology adopted in our work. Section 4 gives the speeches resulting from this research and the discussions on the found statements. Section 5 presents conclusions and future work.

\section{THEORETICAL REFERENCE}

In this section, we present the main concepts used in this research.

\subsection{Collective Subject Discourse}

We can build the Collective Subject Discourse (CSD) from the Theory of Social Representations (Levreve and Lefevre, 2003). The authors initially applied CSD in the field of health to express and process collective opinions. Currently, we can find it in other areas, such as education and computing.

The CSD consists of analyzing verbal material collected from the speeches (such as interviews or questionnaires), the ideas or central anchors, and the fundamental key expressions of these speeches. We compose the statements in the first person singular by the key expressions. Key Expressions (KE) are the most significant passages, and the Central Ideas $(\mathrm{Cl})$ are the synthesis of the discursive content manifested in the KE. Anchors are the explicit linguistic manifestation of the theory, ideology, or belief that the author of the discourse adopts, and the researcher uses it to frame a given situation (Levreve and Lefevre, 2003).

Therefore, the CSD is a methodological approach that uses a discursive strategy to make a more precise social representation and representations that make up imaginary data. 
Through the discursive mode, it is possible to visualize the social presence, which does not appear in an "artificial" way, as figures, tables, or categories, but under a "more vivid and direct" discourse way individuals think about reality.

\section{2- Serious Games and RPG}

The Serious Games have as their primary objective the teaching and learning of people, which can be applied to different knowledge areas and used for various purposes. For Prensky (2001), this type of game, based on learning, transcends traditional education because it is considered fun and pleasure in the game experience, and the elements of learning are not so evident. Therefore, in the use of these games, the following benefits are observed: skill development, engagement and interaction with individuals, more excellent learning and greater control over it, behavior modification, among others (Mota and Adamatti, 2015 and Mota et al., 2016).

RPG is a type of strategy game in which players "play" a character created within a particular scenario, also known as an environment. These characters follow a specific set of rules so that their actions/goals are organized and defined in the game environment (Mero et al., 1998). This type of game is widely used in training, as it can put players in decisionmaking situations similar to the real ones, but without practical consequences. Especially in large companies for employee training courses, RPG does training and learning a particular subject easier due to the playful factor involved in the games (Mero et al., 1998). For the analysis proposed in this article, we used as a case of study an RPG applied to the management of water resources in the context of a hydrographic basin.

\section{MATERIALS AND METHODS}

The development methodology of this work comprised the following steps: i) initial explanation about the proposal of the experiment (game), ii) participation of individuals in an RPG on water resource management, and iii) application of an interview to analyze the engagement and perception of the game. 
We choose randomly the individuals who participated in the experiment sample, invited by email to participate in the game. However, the individuals interviewed were the same who participated in the game, consisting of 16 people (seven women and nine men).

The participants are from Computing and Oceanography Fields, composed of four professors, seven graduate students, and five undergraduate students. The interviewees are between 16 and 66 years old, all Brazilian (ten people live in Rio Grande City and six in Pelotas city).

We constructed the questions based on the methodology proposed by Lefevre and Lefevre (2000), which states that the items must be related to a research objective, that we must ask a set of questions for each target, we must avoid inductions and use questions that lead the individual to discuss the topic, using in these questions adverbs such as: why, how, where, which, among others. Table 1 shows the questions related to each objective and theme used in this research.

Table 1: Questions applied in this research

Subject

Self-perception of the Know the individual's individual's routine

\section{Objective}

1- Do you like games?

2- What period do you usually play?

3- What kind of games do you like?

Self-perception of gambling habits
Know the selfperception of previous gaming habits
4-Do you like strategy games?

5 - Did you know role games before participating in the experiment?

6- If you know, do you usually play?

7- How would you define the term "role games" or RPG?
Possibilities and limitations of the game

\begin{abstract}
Know the motivation and challenges
\end{abstract} present in the game
8- Did you enjoy participating in the game? Why?

9- Do you think the game represents the attitudes of society?

Why? 
10- Do you have any suggestions for improving the game?

Experiments in the Experiment RPG Game
Analyze and substantiate the individual's perspective in the game
11- How was your experience in the role game about the experiment? 12- Did you find it difficult to play during the experiment? Which are?

13- What was your role in the game? What did you think of your role?

14- What strategies did you use during the game?

15- How do you perceive the players' strategies in this experiment?

16- Do you agree with other players' strategies?
Perspectives on the gambling problem
Understand, situate and substantiate the problem of the game
17- Were the players concerned about the environment? Why? 18- How did the game interfere with your perspective on the problem of the game?

19- How would you define the water resource management problem?

Source: Authors (2020)

\section{RESULTS AND DISCUSSIONS}

For this article, we considered five speeches of the questions proposed in the methodology section, three $\mathrm{Cl}$, and their respective anchors. We observed that all composed CSDs were in the first person singular or plural, with the EC of testimonies from the 16 individuals interviewed. The sections underlined in Tables 2, 3, 4, 5, 6, 7, and 8 generated the speeches CSD 1, CSD 2, CSD 3, CSD 4, and CSD 5. The segments not underlined are information that was not considered by not relevant to $\mathrm{KE}$ and $\mathrm{Cl}$. 
From our sample (16 people) and the research data analysis, we can see that $6 \%$ do not like any type of game, $63 \%$ like to play, and $31 \%$ of people are very fond of playing. Regarding the period that people usually dedicate to games, we found that $12 \%$ of people do not have time to play, $50 \%$ of respondents play, and $38 \%$ play frequently. Specifically considering strategy games, we can see that $12 \%$ of people do not like this type of game, $44 \%$ like strategy games and $44 \%$ of respondents are very fond of this play style. Finally, regarding the knowledge before the experiment on RPG games, we assessed that 31\% of the interviewees did not know this type of game, and $69 \%$ had experience with RPG and had ever played.

The collective subject speaks as if it were an individual, that is, as a "natural" discourse of the subject, but that represents several individuals, allowing the emergence, both qualitative and quantitative, of a collective opinion: i) qualitative, it is a discourse with expanded, diversified content for building CSD; and, ii) quantitative, individuals can share the same views, but when these individuals give their opinion, individually, they can transmit or share only part of the theme (Lefevre, 2014). As can be observed in the speeches, we put precisely what the individuals said. Because of this, some answers had misspellings.

Tables 2, 3, 4, 5, 6, 7, and 8 show examples of $\mathrm{KE}, \mathrm{Cl}$, and anchor for questions 8,13 , $14,15,16,17$, and 18 that originated the five speeches. In the KE column, the exact transcriptions of the individuals' responses to the questionnaire are presented, respecting the verb tenses and the original transcriptions; in the $\mathrm{Cl}$ column, we can see the interpretation of these responses; and, in the "anchor" column, we present the theories associated with each $\mathrm{Cl}$.

(Continue) 
Table 2: Question 8 - Did you enjoy playing the game? Why?

\begin{tabular}{ccc}
\hline KE & CI & Anchor \\
\hline $\begin{array}{c}\text { I think that the game allows vast choices, } \\
\frac{\text { in this case, several ways to be taken and }}{\text { raises awareness concerning the intended }}\end{array}$ & $\begin{array}{l}\text { Players' strategies } \\
\text { in the RPG game. }\end{array}$ & RPG Strategies \\
$\begin{array}{c}\text { use of resources because at the end of } \\
\text { these choices, that is, they are entirely }\end{array}$ & & \\
$\underline{\text { free, we can think if I did it well and if I }}$ & & \\
$\underline{\text { didn't, it can have consequences or not. }}$ & & \\
\hline
\end{tabular}

Source: Authors (2020)

Table 3: Question 13 - What was your role in the game? What did you think of your role?

\begin{tabular}{|c|c|c|}
\hline KE & $\mathbf{C i}$ & Anchor \\
\hline $\begin{array}{l}\text { If you followed a logical line as a farmer, you } \\
\text { would first buy what you need plant then } \\
\text { fertilizer for that you will select whether you } \\
\text { will use pesticides or not and then you will } \\
\text { select that you will use machines or not, then } \\
\text { you are using an order correct for things, but } \\
\text { the path you followed will determine if the } \\
\text { person will sell you more expensive or } \\
\text { cheaper than what you are buying. If you } \\
\text { prioritize your gain wanting to buy in the } \\
\text { case you purchase rent a machine and buy } \\
\text { pesticides you may end up paying absurd or } \\
\text { sometimes not even buying the seed } \\
\text { because then the businessman is polluting a } \\
\text { lot and he/she may not want to sell you, and } \\
\text { it is his/her right, then I think it ends up } \\
\text { being the most difficult position not that it is } \\
\text { challenging to play it is more annoying for } \\
\text { you to make decisions. }\end{array}$ & $\begin{array}{c}\text { Players' } \\
\text { strategies in } \\
\text { the role- } \\
\text { playing game }\end{array}$ & RPG Strategies \\
\hline $\begin{array}{l}\text { If you prioritize your profit wanting to buy in } \\
\text { the case you purchase rent a machine and } \\
\text { buy pesticides you may end up paying }\end{array}$ & $\begin{array}{c}\text { Players' } \\
\text { strategies in }\end{array}$ & RPG Strategies \\
\hline
\end{tabular}




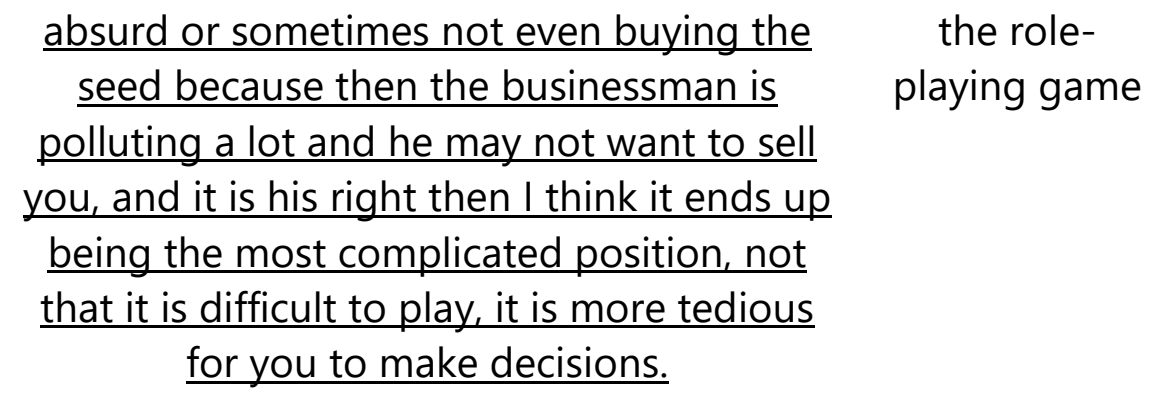

the role-

playing game

This role has, say, two big, two big fields of activity; one is he/she as a producer, so he/she has to decide to buy things and then, that is, he/she makes a bet that should or

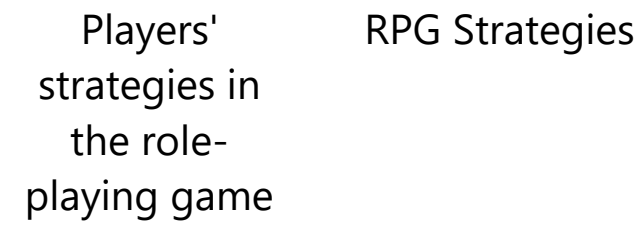

If he/she was a voter because he/she has a role, after all, he/she has a mayor, there is, and this part I did not receive enough element from to playing better, I thought it was very dark because the role of mayor, for example, is assigned he/she is not so, at the same time, I thought well I am also a voter, but in fact, I had no way of influencing as a voter.

Source: Authors (2020)

Table 4: Question 14 - What strategies did you use during the game?

\begin{tabular}{|c|c|c|}
\hline KE & $\mathbf{C l}$ & Anchor \\
\hline $\begin{array}{l}\text { As mayor, I preferred to talk with the } \\
\text { other city to share who would have an } \\
\text { initiative, according to how much each of } \\
\text { the farmers in a given city polluted, we } \\
\text { talked among mayors and decided how } \\
\text { much each would put in financial } \\
\text { resources for the extension of laws on } \\
\text { example river treatment, finally, what was } \\
\text { there as an option and then I acquired } \\
\text { that posture. }\end{array}$ & $\begin{array}{c}\text { Players' strategies } \\
\text { in the role-playing } \\
\text { game }\end{array}$ & RPG Strategies \\
\hline
\end{tabular}


Table 5: Question 15 - How do you perceive the players' strategies in this experiment?

\begin{tabular}{|c|c|c|}
\hline KE & $\mathrm{Cl}$ & Anchor \\
\hline $\begin{array}{l}\text { There are players who, really like a } \\
\text { mirror of society, only want to profit } \\
\text { and want to earn as much as possible. }\end{array}$ & $\begin{array}{c}\text { RPG with } \\
\text { individualistic } \\
\text { strategies and RPG } \\
\text { as an individualistic } \\
\text { survival game }\end{array}$ & $\begin{array}{l}\text { Corruption } \\
\text { Practices and } \\
\text { Strategic Games } \\
\text { to address the } \\
\text { problem }\end{array}$ \\
\hline $\begin{array}{l}\text { Companies try to sell as much as they } \\
\text { can, so they are also not so concerned } \\
\text { with pollution levels, so they try more } \\
\text { to do what they need to survive. }\end{array}$ & $\begin{array}{c}\text { RPG with } \\
\text { individualistic } \\
\text { strategies and RPG } \\
\text { as an individualistic } \\
\text { survival game }\end{array}$ & $\begin{array}{l}\text { Corruption } \\
\text { Practices and } \\
\text { Strategic Games } \\
\text { to address the } \\
\text { problem }\end{array}$ \\
\hline $\begin{array}{l}\text { They only sold what they wanted to } \\
\text { sell, so the machine salesman, I even } \\
\text { think that in the experiment I did, he } \\
\text { always offered me all the possibilities, } \\
\text { but in the case of fertilizer, for } \\
\text { example, and pesticides, I always only } \\
\text { have this type, so, this strategy of } \\
\text { offering a certain type can be personal, } \\
\text { but I couldn't understand why I didn't } \\
\text { know if I was offering the same type to } \\
\text { other consumers. }\end{array}$ & $\begin{array}{c}\text { RPG with } \\
\text { individualistic } \\
\text { strategies and RPG } \\
\text { as an individualistic } \\
\text { survival game }\end{array}$ & $\begin{array}{l}\text { Corruption } \\
\text { Practices and } \\
\text { Strategic Games } \\
\text { to address the } \\
\text { problem }\end{array}$ \\
\hline $\begin{array}{l}\text { There was corruption on the part of } \\
\text { the mayor, the inspector, and a lot, a } \\
\text { lot of pollution but the whole city } \\
\text { collaborated with some petition, so at } \\
\frac{\text { no time was anyone punished for }}{\text { corruption and dishonesty. }}\end{array}$ & $\begin{array}{c}\text { RPG with } \\
\text { individualistic } \\
\text { strategies and RPG } \\
\text { as an individualistic } \\
\text { survival game }\end{array}$ & $\begin{array}{l}\text { Corruption } \\
\text { Practices and } \\
\text { Strategic Games } \\
\text { to address the } \\
\text { problem }\end{array}$ \\
\hline $\begin{array}{l}\text { They seemed to know what they were } \\
\text { doing. It appears that they only got } \\
\text { good economic results due to having } \\
\frac{\text { made agreements not to receive fines, }}{\text { etc. }}\end{array}$ & $\begin{array}{c}\text { RPG with } \\
\text { individualistic } \\
\text { strategies and RPG } \\
\text { as an individualistic } \\
\text { survival game }\end{array}$ & $\begin{array}{l}\text { Corruption } \\
\text { Practices and } \\
\text { Strategic Games } \\
\text { to address the } \\
\text { problem }\end{array}$ \\
\hline
\end{tabular}




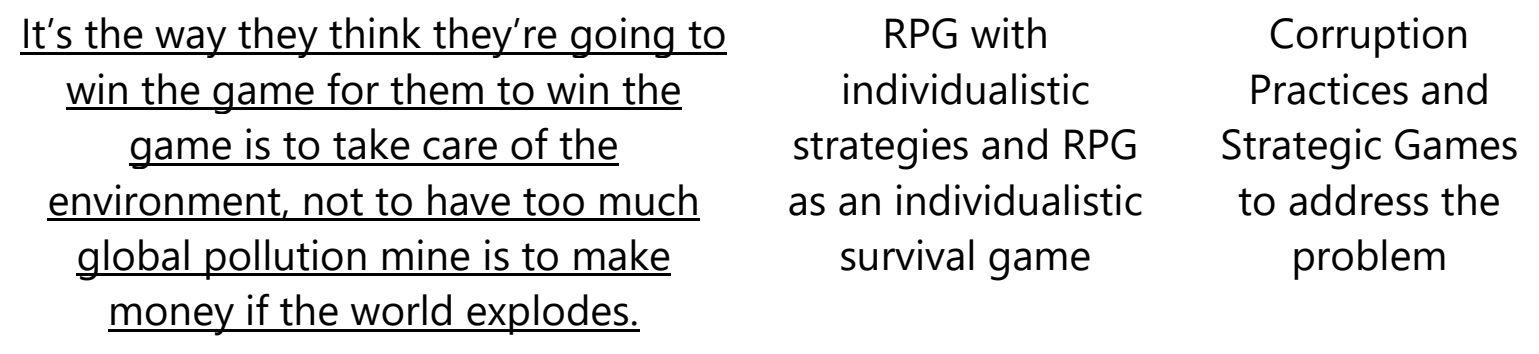

During the match in the first round, as you do not get feedback from anyone, you do not have much to know what people are doing unless you go there and what about doing what no one does, but I believe that from the first round, you can get your first feedback you can see what each one is doing I'm green, the other is polluting, I'm being like polluting the minimum gaining the maximum.
Players' strategies in RPG Strategies the role-playing game
I realized that there were actors, players that I think they had taken. I don't know if because they had participated more often, they had taken some logic, and they acted according to that logic.
Players' strategies in RPG Strategies the role-playing
game

Source: Authors (2020)

Table 6: Question 16 - Do you agree with other players' strategies?

\begin{tabular}{|c|c|c|}
\hline KE & $\mathrm{Cl}$ & Anchor \\
\hline $\begin{array}{l}\frac{\text { the councilors diverted money and had }}{\text { received money for certain things they }} \\
\frac{\text { received directly into their account, so }}{\text { there was a lot of corruption }}\end{array}$ & $\begin{array}{c}\text { RPG with } \\
\text { individualistic } \\
\text { strategies and RPG } \\
\text { as an individualistic } \\
\text { survival game }\end{array}$ & $\begin{array}{c}\text { Corruption } \\
\text { Practices and } \\
\text { Strategic Games } \\
\text { to address the } \\
\text { problem }\end{array}$ \\
\hline $\begin{array}{l}\text { they are strategies, they are not } \\
\text { republican, they are strategies that if they } \\
\text { have to render an account to the society, } \\
\text { they would be unsustainable because }\end{array}$ & $\begin{array}{c}\text { RPG with } \\
\text { individualistic } \\
\text { strategies and RPG }\end{array}$ & $\begin{array}{c}\text { Corruption } \\
\text { Practices and } \\
\text { Strategic Games }\end{array}$ \\
\hline
\end{tabular}




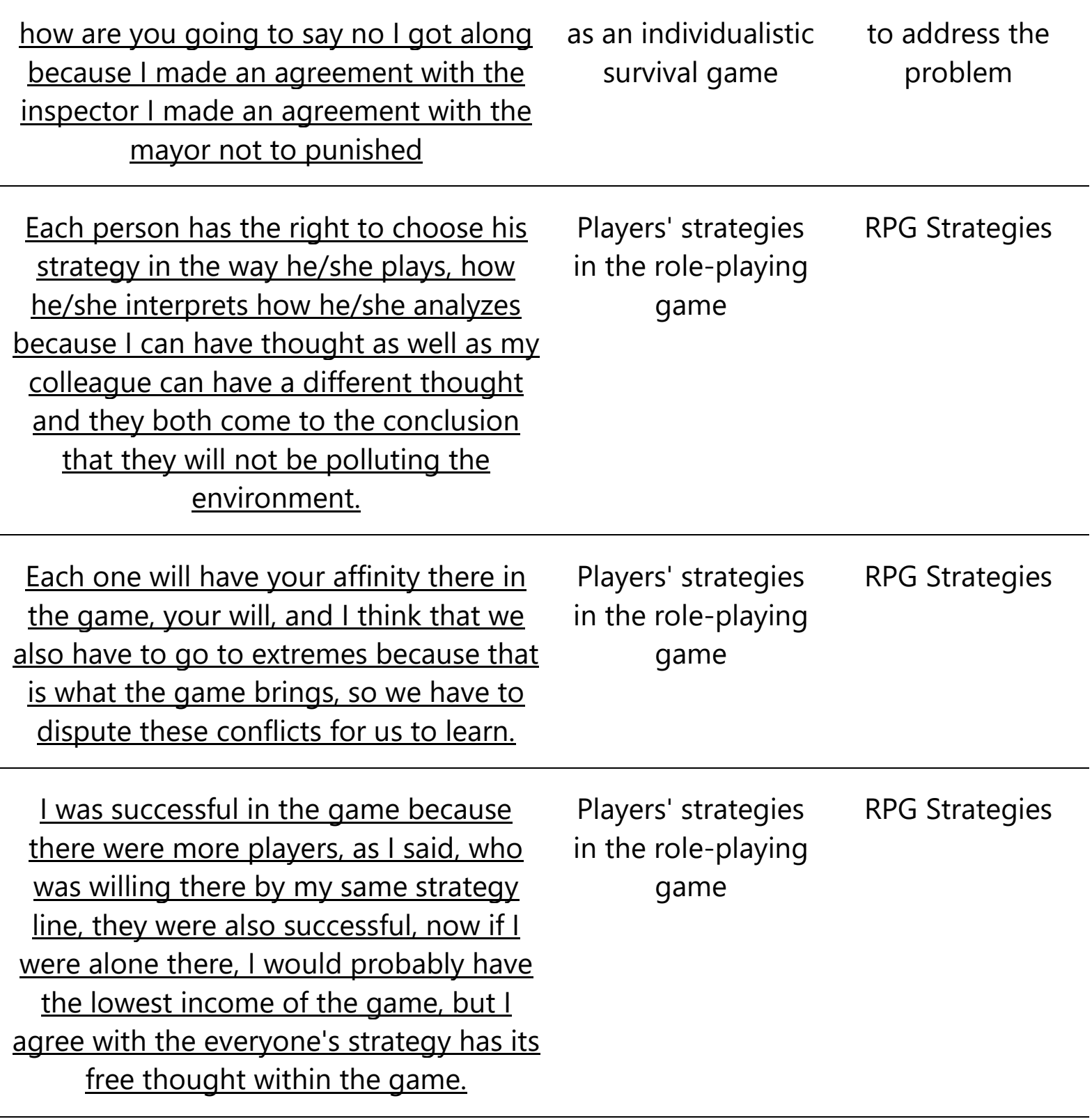

Source: Authors (2020)

Table 7 Question 17 - Were the players concerned about the environment? Why?

\begin{tabular}{|c|c|c|}
\hline KE & CE & Anchor \\
\hline $\begin{array}{l}\text { Whether you agree or not is the risk that we } \\
\text { run in reality, whoever is selling can choose } \\
\text { what they sell and how much. As there is no } \\
\text { competition, it ends up that there is a } \\
\text { cartelization, and then you are forced to buy. }\end{array}$ & $\begin{array}{l}\text { RPG with individualistic } \\
\text { strategies and RPG as } \\
\text { an individualistic } \\
\text { survival game }\end{array}$ & $\begin{array}{l}\text { Corruption } \\
\text { Practices and } \\
\text { Strategic Games } \\
\text { to address the } \\
\text { problem }\end{array}$ \\
\hline
\end{tabular}


I saw a specific one who was specifically concerned with profit, including he/she was the one with the highest value in the account, but he/she also polluted a lot, so I saw that there they were not considering anything concerning pollution nothing concerning the environment nothing in relation other people were only looking for his profit.
RPG with individualistic strategies and RPG as an individualistic survival game
Corruption

Practices and

Strategic Games

to address the problem
He/She realized that as the pollution increased, we could see that the staff was mainly concerned with their goal of making a profit and when it came to the issue of the mayor, inspector we realized that sometimes there was a lot of corruption that would be a diversion of money and did not care about environmental preservation.

$\begin{array}{cc}\text { RPG with individualistic } & \text { Corruption } \\ \text { strategies and RPG as } & \text { Practices and } \\ \text { an individualistic } & \text { Strategic Games } \\ \text { survival game } & \text { to address the } \\ & \text { problem }\end{array}$

RPG with individualistic

Practices and

Strategic Games

problem
They were concerned not with the environment, they were worried about not being fined, so one thing led to another
RPG with individualistic strategies and RPG as an individualistic survival game
Corruption Practices and Strategic Games to address the problem

\section{People tend to think they are environmentalists like that, but they end up doing a lot of things that harm the environment like that before they make the right decisions}

it turns out that if we notice everyone is concerned with this issue, everyone thinks it is possible to reverse everything that is done, so it's okay; I pollute now because later I can reverse it, I'll have money do it.

When it was very common, they were worried, but when it was for their benefit, then if I am going to earn more, let's pollute that after somebody does maintenance on it, then not everyone was worried and not at all times
Everyone was concerned about the environment, but the idea is that everyone
RPG with individualistic strategies and RPG as an individualistic survival game
Corruption

Practices and Strategic Games to address the problem
RPG with individualistic strategies and RPG as an individualistic survival game

\section{Corruption} Practices and Strategic Games to address the problem

RPG with individualistic strategies and RPG as an individualistic survival game
Corruption Practices and Strategic Games to address the problem $\begin{array}{cc}\text { RPG with individualistic } & \text { Corruption } \\ \text { strategies and RPG as } & \text { Practices and }\end{array}$ 


\begin{tabular}{|c|c|c|}
\hline $\begin{array}{l}\text { tries to profit you and I think the biggest } \\
\text { concern of the agents was not taking a fine }\end{array}$ & $\begin{array}{l}\text { an individualistic } \\
\text { survival game }\end{array}$ & $\begin{array}{l}\text { to address the } \\
\text { problem }\end{array}$ \\
\hline $\begin{array}{l}\text { some because they didn't want to lose the } \\
\text { game because they thought that if they } \\
\text { polluted a lot, they would lose the game; in } \\
\text { my case, that didn't apply because I wanted } \\
\text { to make money so that I couldn't care less. }\end{array}$ & $\begin{array}{l}\text { RPG with individualistic } \\
\text { strategies and RPG as } \\
\text { an individualistic } \\
\text { survival game }\end{array}$ & $\begin{array}{l}\text { Corruption } \\
\text { Practices and } \\
\text { Strategic Games } \\
\text { to address the } \\
\text { problem }\end{array}$ \\
\hline $\begin{array}{l}\text { We managed to realize that it is not } \\
\text { necessarily the fine that was freeing the } \\
\text { environment from being polluted, but the } \\
\text { actions of those who have the power to } \\
\text { implement actions that reduce pollution. So, } \\
\text { even though it is low, monitoring it will not } \\
\text { generate high pollution if the executive } \\
\text { power takes the necessary actions to fight } \\
\text { pollution at the stage that the game is } \\
\text { currently in. }\end{array}$ & 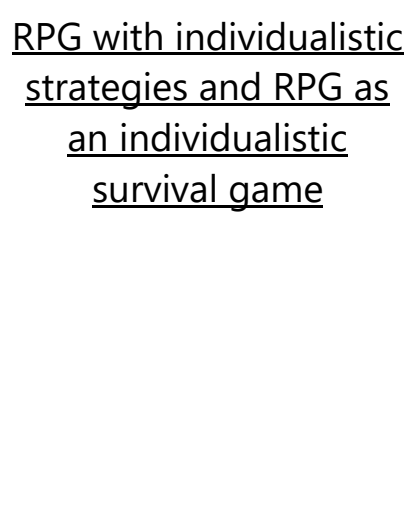 & $\begin{array}{l}\text { Corruption } \\
\text { Practices and } \\
\text { Strategic Games } \\
\text { to address the } \\
\text { problem }\end{array}$ \\
\hline $\begin{array}{l}\frac{\text { Financial resources prove to be much more }}{\text { important than the well-being of the }} \\
\text { environment at some point for some fellow } \\
\text { players. }\end{array}$ & $\frac{\frac{\text { RPG with individualistic }}{\text { strategies and RPG as }}}{\frac{\text { an individualistic }}{\text { survival game }}}$ & $\begin{array}{l}\text { Corruption } \\
\text { Practices and } \\
\text { Strategic Games } \\
\text { to address the } \\
\text { problem }\end{array}$ \\
\hline $\begin{array}{l}\text { They include in their income the risk of } \\
\text { paying the fine, so I think the concern is in } \\
\text { this aspect, which is what most appears; I } \\
\text { don't know if everyone really cares }\end{array}$ & $\begin{array}{l}\text { RPG with individualistic } \\
\text { strategies and RPG as } \\
\text { an individualistic } \\
\text { survival game }\end{array}$ & $\begin{array}{l}\text { Corruption } \\
\text { Practices and } \\
\text { Strategic Games } \\
\text { to address the } \\
\text { problem }\end{array}$ \\
\hline $\begin{array}{l}\text { they cared about the environment, pollution, } \\
\text { and other players who just wanted to profit; } \\
\text { the money went for the fun part of the game. }\end{array}$ & $\begin{array}{l}\text { RPG with individualistic } \\
\text { strategies and RPG as } \\
\text { an individualistic } \\
\text { survival game }\end{array}$ & $\begin{array}{l}\text { Corruption } \\
\text { Practices and } \\
\text { Strategic Games } \\
\text { to address the } \\
\text { problem }\end{array}$ \\
\hline
\end{tabular}

Source: Authors (2020)

Continue ... 
Table 8: Question 18 - How did gambling interfere with your perspective on the gambling problem?

\begin{tabular}{|c|c|c|}
\hline KE & CE & Anchor \\
\hline $\begin{array}{l}\text { The game brings a lot of corruption } \\
\text { because, in fact, those who pollute more, } \\
\text { those who produce more earn much } \\
\text { more money, which happens a lot today } \\
\text { in reality. }\end{array}$ & $\begin{array}{c}\text { RPG with } \\
\text { individualistic } \\
\text { strategies and RPG as } \\
\text { an individualistic } \\
\text { survival game }\end{array}$ & $\begin{array}{l}\text { Corruption } \\
\text { Practices and } \\
\text { Strategic Games } \\
\text { to address the } \\
\text { problem }\end{array}$ \\
\hline $\begin{array}{l}\text { People act to earn money as I did, I don't } \\
\text { know if in real life I would do that I will } \\
\text { not lie I may if I would do it maybe, but I } \\
\text { saw there that you could keep a clean } \\
\text { city without clear pollution always will, } \\
\text { but you can keep the minimum, but you } \\
\text { keep the minimum and everything else } \\
\text { you will not earn anything, and people } \\
\text { want to earn money, so that's why I } \\
\text { started all this happening. }\end{array}$ & $\begin{array}{c}\text { RPG with } \\
\text { individualistic } \\
\text { strategies and RPG as } \\
\text { an individualistic } \\
\text { survival game }\end{array}$ & $\begin{array}{l}\text { Corruption } \\
\text { Practices and } \\
\text { Strategic Games } \\
\text { to address the } \\
\text { problem }\end{array}$ \\
\hline $\begin{array}{l}\text { It is not just inside the game that there } \\
\text { are people who are corrupt, and there } \\
\text { are people who are good, who do the } \\
\text { right things, and we see the impact that } \\
\frac{\text { this has in a controlled environment as }}{\text { well as outside. }}\end{array}$ & $\begin{array}{c}\text { RPG with } \\
\text { individualistic } \\
\text { strategies and RPG as } \\
\text { an individualistic } \\
\text { survival game }\end{array}$ & $\begin{array}{l}\text { Corruption } \\
\text { Practices and } \\
\text { Strategic Games } \\
\text { to address the } \\
\text { problem }\end{array}$ \\
\hline
\end{tabular}

Source: Authors (2020)

We elaborate DSC 1, DSC 2, and DSC 3 speeches from the anchors ("Corruption Practices" and "Strategic Games in the face of the problem") and the Cl ("RPG with individualist strategies and RPG as an individualist survival game") derived from questions 15, 16, 17 and 18. 
There are players who, really like a mirror of society, who only want to aim for profit and want to earn as much as possible; companies try to sell as much as they can, so they are also not so concerned with the levels of pollution, so they try to do more what they need to survive. They only sold what they wanted to sell, so the machine salesman, I even think that in the experiment I did, he always offered me all the possibilities, but in the case of fertilizer, for example, and pesticides, I always only have this type, So, this strategy of offering a certain type can be a personal strategy, but I couldn't understand why I didn't know if I was offering the same type to other consumers, there was corruption on the part of the mayor, the inspector and a lot, a lot of pollution but the whole city collaborated with some petition so at no time was anyone punished for corruption and dishonesty, they seemed to know what they were doing, it seems to me that they only got good economic results due to having made agreements not to receive fines, etc. It's the way they think they're going to win the game for them to win the game is to take care of the environment not to have too much global pollution mine is to make money if the world explodes, councilors diverted money and had received money for certain things they received directly into their own account so there was a lot of corruption. So, they are strategies, they are not republican strategies that if they have to give an account to the society, they would be unsustainable because how are you going to say no I got along because I made an agreement with the inspector I made a deal with the mayor not to punished.

\section{CSD1: Corruption as a game strategy.}

The game brings a lot of the problem of corruption because those who pollute more, those who produce more earn much more money, and this happens a lot today in reality. Whether you agree or not is the risk that we run in fact, whoever is selling can choose what they sell and how much too. As there is no competition, it ends up that there is a cartelization, and then you are forced to buy. I saw a specific one who was specifically concerned with profit, including he/she was the one with the highest value in the account, but he/she also polluted a lot, so I saw that there they were not considering anything concerning pollution nothing about the environment nothing in relation other people were only looking for his profit, he/she realized that as the pollution increased, we could see that the staff was mainly concerned with their goal of making a profit and when it came to the issue of the mayor, inspector, we realized that sometimes there was a lot of corruption that would be the diversion of money and didn't care about environmental preservation. So, people act to earn money as I did, I don't know if in real life I would do that I will not lie I may if I would do it maybe, but I saw there that you could keep a clean city without clear pollution always will, but you can keep the minimum, but you keep the minimum and everything else, you will not earn anything, and people want to make money, so that's why I started all this happening. They were concerned not with the environment, they were worried about not being fined, so one thing led to another. People tend to think they are 
environmentalists like that, but they end up doing a lot of things that harm the environment like that before they make the right decisions, it turns out that if we notice everyone, if this concerned with this issue, but everyone thinks that it is possible to reverse everything that is done, so it's okay, I pollute now because later I can reverse it, I'll have money to do it.

\section{CSD2: Players' strategies regarding corruption and fines.}

When it was very common, they were worried, but when it was for their benefit, then if I am going to earn more, let's pollute that after somebody does maintenance on it, then not everyone was worried and not at all times. Everyone was concerned about the environment, but the idea is that everyone tries to profit you and I think the biggest concern of the agents was not taking a fine, some because they didn't want to lose the game because they thought that if they polluted a lot, they would lose the game in my case that didn't apply because I wanted to make money so I couldn't care less. We managed to realize that it is not necessarily the fine that was freeing the environment from being polluted, but the actions of those who have the power to implement actions that reduce pollution. So, monitoring it, even though it is low, monitoring it will not generate high pollution if the executive power takes the necessary actions to fight pollution at the stage that the game is currently in. Financial resources prove to be much more important than the well-being of the environment at some point for some fellow players, they include in their income the risk of paying the fine, so I think the concern is in this aspect, which is what most appears, I don't know if everyone really cares. However, it is not just inside the game that there are people who are corrupt and there are people who are good, who do the right things, and we see the impact that this has in a controlled environment as well as outside, but they cared about the environment, about pollution and other players who just wanted to get the profit, the money went for the fun part of the game.

\section{CSD3: The financial resource as the main strategy of the players.}

CSD 1, CSD 2, and CSD 3 demonstrated the importance of RPG players' strategies and the influence of financial resources and corruption in their decision making. Mero et al. (1998) point out that RPG is a strategy game that allows individuals to interpret characters from a set of rules in a given environment. Regarding corruption, Ribeiro (2010) highlights that this occurs when a member of an organization or institution uses his position, her/his rights, or something restricted to the position he occupies to obtain economic or personal advantage for her/his benefit or that of third parties. Privado (2017) highlights that 
corruption, especially in the public sphere, reduces foreign investors' confidence in the country and can affect its governance model. Therefore, it is necessary to reflect on governance, and public administration practices since corruption in this area can directly change the perception and control of what the country implements.

We develop CSD 4 and CSD 5 speeches from the anchor ("Strategies of the RPG") and the $\mathrm{Cl}$ ("Strategies of the players in the game of RPG") originated from questions $8,13,14$, 15 , and 16 .

I think that the game allows the player vast choices, in this case, several ways to be taken and raises awareness concerning the conscious use of resources because at the end of these choices, that is, they are entirely free, we can think if I did it well and if I didn't, it can have consequences or not. If you followed a logical line as a farmer, you would first buy what you need plant then fertilizer for that you will select whether you will use pesticides or not and then you will select that you will use machines or not, then you are using an order correct for things, but the path you followed will determine if the person will sell you more expensive or cheaper than what you are buying. If you prioritize your profit buying, in the case, you buy rent a machine and buy pesticides; you may end up paying absurd or sometimes not even buying the seed because then the businessman is polluting a lot and he/she may not want to sell you, and it is his/her right then I think it ends up being the most complicated position, not that it is challenging to play, it is more annoying for you to make decisions. Each person has the right to choose his/her strategies in the way he/she plays, how he/she interprets how he/she analyzes because I can have thought as well as my colleague can have a different thought and the both come to the conclusion that they will not be polluting the environment. Each one will have your affinity there in the game, your will, and I think that we also have to go to extremes because that is what the game brings, so we have to dispute these conflicts for us to learn.

\section{CSD4: The strategy options in the game.}

During the match in the first round, as you do not get feedback from anyone, you do not have much to know what people are doing unless you go there and what about doing what no one does, but I believe that from the first round, you can get your first feedback you can see what each one is doing I'm green, the other is polluting, I'm being like polluting the minimum gaining the maximum. I realized that there were actors, players that I think they had taken; I don't know if because they had participated more often, they had taken some logic, and they acted according to that logic. This role has, say, two big, two big fields of activity; one is he/she as a producer, so he/she has to decide to buy things and then, that is, he/she makes a bet that should or should 
involve things of economic and environmental values. If he/she was a voter because he/she has a role, after all, he/she has a mayor, there is, and this part I did not receive enough elements to play better, I thought it was very dark because the role of mayor, for example, is assigned $\mathrm{h} / \mathrm{she}$ is not so, at the same time, I thought well I am also a voter, but in fact, I had no way of influencing as a voter. As mayor, I preferred to talk with the other city to share who would have an initiative, according to how much each of the farmers in a given city polluted, we talked among mayors and decided how much each would put in financial resources for the extension of laws on example river treatment, finally, what was there as an option and then I acquired that posture. I was successful in the game because there were more players, as I said, who was willing there by my same strategy line, they were also successful, now if I were alone there, I would probably have the lowest income of the game, but I agree with the everyone's strategy has its free thought within the game.

\section{CSD5: The use of feedback in the strategies of the players.}

CSD 4 and CSD 5 speeches demonstrated the importance of choice options and ingame feedback to build their strategies. Mero et al. (1998) point out that for an RPG game to occur, it is necessary to have a set of rules that determine the game's objective and possible actions to interpret a character in a given environment. Tessaro and Jordão (2007) point out that when used in a learning process, the game needs an objective direction of the knowledge that it wants to provide about the theme that it intends to address. Vygotsky (1988) states that a learning process occurs from individuals' interactions in a game, which provides conditions for them to exercise an imaginary plane in a specific situation. Finally, Duarte et al. (2016) highlight that feedback is essential for the learning process to occur, as its presence helps players overcome game levels and achieve their goals.

\section{CONCLUSIONS}

In this article, we analyzed the Collective Subject Discourse (CSD) using RPG in Water Resources Management. This work's main contribution is the analysis of the habits and strategies of individuals during the RPG. In the context of learning, the game can help understand the problem, making it possible to analyze how each player observes a situation from her/his perspective and how s/he develops strategies for her/his role in the game. 
The data were analyzed using the CSD technique, configuring a qualitative and quantitative analysis of a verbal nature, resulting in five synthesis speeches, written in the first person singular or plural. Finally, we consider that games, especially RPG, can assist individuals in the learning process by providing scenarios to experience new real-world actions during the game.

As future work, we propose i) to develop a virtual assistant to assist players in discourse analysis, ii) automate the collective subject discourse analysis methodology, and iii) verify changes in the RPG based on the interviewees' suggestions.

\section{ACKNOWLEDGMENTS}

This study was financed by the Coordenação de Aperfeiçoamento de Pessoal de Nível Superior (CAPES/Brazil) and Agência Nacional de Águas (ANA/Brazil) -- Edital Nº 16/2017.

\section{REFERENCES}

ADAMATTI, D. F.; SICHMAN, J. S.; BOMMEL, P.; DUCROT, R.; RABAK, C.; CAMARGO, M. E.; JogoMan: A prototype using multi-agent-based simulation and role-playing games in water management. In: Proceedings of the Smaget-cabm-hema Conference, 2005.

BARBOSA, M. A. G. A.; da SILVA ANJINHO, P.; dos SANTOS, A. R.;OKAWA, C. M. P.; MAUAD, F. F. Maximum streamflow: brief description of concepts and methods of regionalization. Revista Eletrônica em Gestão, Educação e Tecnologia Ambiental, v. 23, p. 42, 2019.

CHACON-PEREIRA, A.; da SILVA BATALHÃO, A. C.; da SILVA, L. P.; NEFFA, E. Educação ambiental na gestão de recursos hídricos baseada no modelo de licenciamento ambiental. Desenvolvimento e Meio Ambiente, v. 49, 2018.

CHOI D.; KIM J. Why people continue to play online games: In search of critical design factors to increase customer loyalty to online contents. CyberPsychology \& behavior, 7(1):11-24, 2004.

DUARTE G. B.; ALDA L .S.; LEFFA V. J. Gamificação e o feedback corretivo: considerações sobre a aprendizagem de línguas estrangeiras pelo Duolingo. Raído. 2016;10(23):114-28.

FOGG, B.J. Persuasive technology: using computers to change what we think and do.Stanford University, p.2, 2002.

FOLETO, E. M. (2018). O CONTEXTO DOS INSTRUMENTOS DE GERENCIAMENTO DOS RECURSOS HÍDRICOS NO BRASIL. Geoambiente On-Line, (30). https://doi.org/10.5216/revgeoamb.v0i30.52823. 
JACOBI, P. R.; FRANCALANZA, A. P. Comitês de bacias hidrográficas no Brasil: desafios de fortalecimento da gestão compartilhada e participativa. Desenvolvimento e Meio Ambiente, v. 11, 2005.

LEFEVRE, F.; LEFEVRE, A. B. M.; TEIXEIRA, J. J. O discurso do sujeito coletivo: uma nova abordagem metodológica em pesquisa qualitativa. In: O discurso do sujeito coletivo: uma nova abordagem metodológica em pesquisa qualitativa, pp. 138-138, 2000.

LEVEVRE, F.; LEFEVRE, A. M. O discurso do sujeito coletivo: Um enfoque em pesquisa qualitativa. Caxias do Sul: Pensamento Editora, 3. ed., 2003.

LEFEVRE, F.; LEFEVRE, A. M. Discourse of the collective subject: social representations and communication interventions. Texto \& Contexto-Enfermagem, 23(2):502-7, 2014.

de LIMA, J. M. O jogo como recurso pedagógico no contexto educacional. São Paulo: Cultura Acadêmica: Universidade Estadual Paulista, Pró-Reitoria de Graduação, 2008.

MERO, G. T.; MERO, M. J.; MERO, G. T.; MICHAEL J. Role playing game. United States patent US 5,810,666, 1998.

MOTA, F. P.; ADAMATTI, D. F. Programming teaching in high schools: An analysis based on the discourse of collective subject. In: 2015 IEEE Frontiers in Education Conference (FIE), pp. 1-5, IEEE, 2015.

MOTA, F.; BOTELHO, S. C. B.; ADAMATTI, F. D. Serious Games as a Tool to Change People Attitudes: Analysis Based on the Discourse of Collective Subject. Literacy Information and Computer Education Journal (LICEJ),7(4):2398-405, 2016.

PRIVADO, E. O. P. E. O. Paradoxos entre governança corporativa e ocorrência de práticas de corrupção em empresas públicas: uma análise a luz da teoria da agência, 2017.

PRENSKY M. Digital natives, digital immigrants. On the horizon, 9(5), 2001.

RIBEIRO I. L. Patrimonialismo e personalismo: a gênese das práticas de corrupção no Brasil. Anais do XIX Encontro Nacional do CONPEDI. 2010 Jun.

TESSARO, J. P.; JORDÃO, A. P. Discutindo a importância dos jogos e atividades em sala de aula. Psicologia. com. pt, o portal dos psicólogos; 2 (08), 2007.

VYGOTSKY L. S. Aprendizagem e desenvolvimento intelectual na idade escolar. Linguagem, desenvolvimento e aprendizagem,10:103-17, 1988.

WAHRLICH, J.; de ALVARENGA, R. A. F.; HENKES, J. A.; DE FÁTIMA ROSSATO, I.; SIMIONI, F. J. Avaliação Da Sustentabilidade Do Ciclo De Vida: Uma Revisão. Revista Gestão \& Sustentabilidade Ambiental, v. 9, n. 2, p. 183-201, 2020. 


\section{AUTHORSHIP CONTRIBUTIONS}

\section{1 -Fernanda P. Mota:}

$\mathrm{PhD}$ in Science Education in the Graduate Program in Science Education: Life Chemistry and Health. https://orcid.org/0000-0003-3829-3075 | E-mail: nandapm2010@gmail.com

Contribuition: Conceptualization | Data curation | Formal Analysis | Methodology | Supervision Validation | Writing - original draft.

\section{2 - Míriam B. Born:}

PhD student in Computer Science

https://orcid.org/0000-0002-5551-1444 | E-mail: miriamborn@gmail.com

Contribuition: Conceptualization| Data curation | Formal Analysis | Methodology| Supervision Validation | Writing - original draft.

\section{3 - Marilton S. de Aguiar:}

Master's and doctorate in Computer Science

https://orcid.org/0000-0002-5247-6022 | E-mail: marilton@inf.ufpel.edu.br

Contribuition: Project administration | Resources | Supervision Validation | Writing - review \& editing.

\section{4 - Diana F. Adamatti:}

$\mathrm{PhD}$ in Electrical Engineering (Emphasis on Digital Systems and Computer Engineering)

https://orcid.org/0000-0003-3829-3075 | E-mail: dianaada@gmail.com

Contribuition: Project administration | Resources | Supervision Validation | Writing - review \& editing.

\section{HOW TO QUOTE THIS ARTICLE}

Mota, F. et.al. The Strategies of the Players of an RPG Game in the Context of Water Resources Management: an analysis based on the Discourse of the Collective Subject. Revista de gestão, educação e tecnologia ambiental. Santa Maria, v.25, e1, 2021. Available from: https://doi.org/10.5902/2236117055298. Accessed: Month Abbreviated. Day, year. 